\title{
The differences in production of Holstein Friesian and Holstein Friesian x Norwegian Red F1 crossbreeds
}

\author{
Stipo Benak', Tina Bobić2*, Katarina Bilandžija ', Zvonimir Stainer², \\ Ana Aračić ${ }^{3}$, Maja Gregić², Domagoj Eman ', Vesna Gantner²
}

\begin{abstract}
'Belje plus d.o.o., Sv. Ivana Krstitelja 1, 31326 Darda, Croatia
${ }^{2}$ University of J. J. Strossmayer in Osijek, Faculty of Agrobiotechnical Sciences Osijek, Department for animal production and biotechnology Osijek, Vladimira Preloga 1, 31000 Osijek, Croatia

${ }^{3}$ BELJE AGRO-VET plus d.o.o., Kokingrad 4, Mece, 31326 Darda, Croatia

${ }^{*}$ Corresponding author: tbobic@fazos.hr
\end{abstract}

\section{Abstract}

The aim of this study was to compare the production, health and fertility traits of Holstein Friesian (HF) and their F1 crosses with Norwegian Red cows (HF x NRF F1). Only the production data's from finished first lactations of the total $57 \mathrm{HF} \times \mathrm{NRF} F 1$ crosses and $401 \mathrm{HF}$ cows, and for health and fertility traits of $120 \mathrm{HF} \times$ NRF F1 crosses and $255 \mathrm{HF}$ cows, were used. The differences in production traits were tested by a least square means using the GLM procedure in SAS. The milk yield in both lactation (standard 305 days and full lactation) were higher in HF x NRF F1 crosses for approximately 400 kg, but without significance. The differences in production traits (fat and protein ( $\mathrm{kg}$ and \%)) were significant $(p<0.001 ; p<0.05)$ with higher values for HF x NRF F1 crosses comparing to HF cows, with exception of protein in full lactation. Regarding the fertility traits, HF x NRF F1 crosses had a better conception rate $(+1.58 \%)$, a lower number of the insemination per pregnancy $(-0.43)$ and a shorter duration of the service period (-22.2) comparable to HF cows. F1 crosses had better health traits (with except for hoofs problem) comparing to HF cows, they had less cows with mastitis $(-11.9 \%)$, ketosis (-0.5 \%), retained placenta $(-4.8 \%)$ and dislocation of the abomasum (-1.0\%), respectively. Because of the fact that all results were obtained on the basis of data from the first lactation cows, it is necessary to do more analyses of all studied traits in subsequent lactations, in order to get a much clearer insight into the studied issues.

Key words: production traits, health traits, fertility traits, Holstein Friesian, Holstein Friesian $\mathrm{x}$ Norwegian Red F1 crossbreeds 


\section{Introduction}

After the long-term breeding work in dairy production aimed at achieving high production per cow, the fertility, longevity, and health traits have been reduced (Seegers et al., 2003; Windig et al., 2005; Hare et al., 2006). Consequently, the economic losses are increasing. Weller (1994) pointed out the progeny of the crosses are more profitable than either parental breed. According to Weigel and Barlass (2003) the use of crossbreed cows may be an alternative solution to combine good production and fitness. Dechow et al. (2007) pointed out that the first crossbreed generation tended to exhibit better functional traits and fat production than purebred cows. Further, Weigel (2007) emphasized that crossbreeding had less influence on production traits than on functional traits. According to Dechow et al. (2007) crossbreeding contributes to a substantial increase in the economic performance of dairy production systems, mostly for longevity and functional traits, except for mastitis, and somewhat lower for milk production. Sørensen et al. (2008) emphasized if crossbreeding is used at the expense of genetic gain in the pure breeds, the overall economic benefit over time will be negatively affected. When used properly, heterosis can be a bonus on top of the gain from traditional dairy cattle breeding programs. On contrary, Ezra et al. (2016) stated that crossbreeding is a common strategy for most agricultural animal species, including poultry, swine, sheep and beef cattle but for dairy cattle crossbreeding has generally not been considered as an economically viable option. According to Buckley et al. (2014) the economic improvement using crossbreeding can be achieved by introducing favourable genes from another breed selected more strongly for traits of interest; removing the negative effects associated with inbreeding depression; or by benefits of heterosis effect. Crossbreeding is of particular interest for dairy producers focusing on functional traits, because heterosis effects tend to be greater for these traits. According to many researches, heterosis for various crossbreeds, ranged (in percentage) from 1.7 to 8.4 for fat, and from 1.5 to 8.2 for proteins (Ericson et al., 1988; Touchberry 1992; VanRaden and Sanders, 2003; Dechow et al., 2007; Sørensen et al., 2008). In dairy cattle production, the Holstein Friesian breed is the leader breed, but according to Pryce et al. (2014) intensive selection for an increased milk yield resulted in unfavourable correlated responses for health and fertility in that breed. On the other hand, the breeding goal of the Norwegian Red focused on fertility and health along with milk production (Miglior et al., 2005). Resulting therefrom, the Norwegian Red cattle and their crossbreeds with Holsteins have better fertility, a lower somatic cell count and a lower incidence of mastitis (Heins et al., 2006; Begley et al., 2009; Cartwright et al., 2011; Heins and Hansen, 2012). The same was confirmed by results of Rinell and Heringstad (2018), which stated that crossbreeding Norwegian Red and Holstein can produce cows with better fertility that are less susceptible to postpartum disorders. Therefore, the aim of this study was to compare the production, health and fertility traits between Holstein Friesian cows and there F1 crosses with Norwegian Red cows ( $\mathrm{Hol}-$ stein Friesian x Norwegian Red F1 crossbreeds) after finished first lactations at Croatian conditions.

\section{Material and methods}

The research was conducted at commercial dairy farm in company Belje Ltd., in the period from August 2015 to June 2016. The five Norwegian Red bulls (NRF): Dahle, Skei, Skjelvan, Gopollen and Rosnes were used for a one-way insemination of the 1.564 Holstein Friesian (HF) cows, while in the same period $3.493 \mathrm{HF}$ cows were inseminated with Holstein bulls. All cows (HF and F1 crosses) were in the same microclimate condition, fed by the same food and all of them it was managed on the same way. For this research, only the production data from finished first lactations of the total $57 \mathrm{HF} x$ NRF F1 crosses and 401 HF cows, and for health traits total $120 \mathrm{HF} \times \mathrm{NRF}$ F 1 crosses and $255 \mathrm{HF}$ cows, were used. Regarding the calving date, animals were divided into two calving season classes (S - March, April, May, Jun, July, and August; W - September, October, November, December, January, and February). 


\section{Statistical analysis}

The differences in production traits of Holstein Friesian (HF) and Holstein Friesian x Norwegian Red F1 crossbreeds (HF x NRF) were tested using least square means in GLM procedure in SAS (SAS Institute Inc., 2000). Following statistical model was used:

$$
y_{i j k l}=\mu+b_{1} a_{i}+B_{j}+S_{k}+e_{i j k l}
$$

Where:

/ $\mathrm{y}_{\mathrm{ijk}}=$ estimated production trait: Milk yield (kg) in standard lactation (M 305); Milk yield (kg) in full lactation (M Lac); Fat yield (kg) in standard lactation (SF); Fat yield (kg) in full lactation (LF); Protein yield (kg) in standard lactation $(\mathrm{SP})$; Protein yield $(\mathrm{kg})$ in full lactation $(\mathrm{LP})$; Percentage value of the fat (\%) in standard lactation (SFP); Percentage value of the fat (\%) in full lactation (LFP); Percentage value of the protein (\%) in standard lactation (SPP) and Percentage value of the protein (\%) in full lactation (LPP);

/ $\mu=$ intercept;

$/ b_{1}=$ regression coefficients;

/ $\mathrm{a}_{\mathrm{i}}=$ age at calving as linear regression

( $i=630$ to 1080 days);

/ $B_{j}=$ fixed effect of breed class $j$

$(\mathrm{j}=\mathrm{HF} / \mathrm{HF} \times \mathrm{NRF})$;

/ $S_{k}=$ fixed effect of calving season class $k$

$(k=S / W)$;

/ $\mathrm{e}_{\mathrm{ij \textrm {k }}}=$ residual.

The significance of the differences in production traits between the analysed breeds (HF / HF x NRF) was tested by t-test.

In order to compare HF and HF x NRF crossbreeds regarding the fertility traits, prevalence of health disorders as well as the reasons of culling, the results of a farm manager program analysis were used. Following fertility traits was used: Conception rate (\%) (calculated on the basis of the ratio of the number of used seed doses and the number of pregnant cows, presented as percentage); Insemination per pregnancy (n) (number of seed doses used per cow); Days open (days) (number of days from beginning of the lactation until confirm of pregnancy). As health traits the prevalence of mastitis, retained placenta, ketosis, displaced abomasum and lameness were used.

\section{Results and discussion}

The Holstein Friesian cows had in average $8278.00 \mathrm{~kg} \mathrm{M} \mathrm{305,} 343.10 \mathrm{~kg}$ SF, $274.20 \mathrm{~kg}$ of the SP, with 4.17 and $3.33 \%$ of SFP and SPP, respectively (Table 1). The range of the M 305 were between 2720.70 and $14206.90 \mathrm{~kg}$. Furthermore, the F1 crosses (HF x NRF) had higher values of M 305 comparing to the HF cows, with exception of the maximum milk yield. The average milk yield was 8 $672.29 \mathrm{~kg}$, while it ranged between 4980.00 and 14 102.70. The SF and SP were in range from 3.44 $\%$ to $5.38 \%$ and from $2.99 \%$ to $4.03 \%$, and in average were 4.40 and $3.38 \%$.

When comparing the results from full lactation among the analysed breeds, crossbreeds had also higher values in regards to Holstein Friesian. The average production of the crossbreds was 9358.98 $\mathrm{kg}$ for M Lac, $409.02 \mathrm{~kg}$ for LF and $315.66 \mathrm{~kg}$ for LP, which is higher compared to $9057.94 \mathrm{~kg}$ for M Lac, $377.04 \mathrm{~kg}$ for LF and $301.90 \mathrm{~kg}$ for LP, obtained of the HF cows.

According to the results presented in Table 2., which are referring to standard and full lactation, all study traits were higher for crossbreeds comparing to Holstein Friesian cows. The highest difference (over $400 \mathrm{~kg}$ ) was found in the milk yield, but it was not statistically significant. A significant $(p<0.001)$ difference among breeds regarding the SF and SFP, and the significance $(p<0.05)$ difference for the SP, were established. Similar results were found in full lactation, approximately 400 kg (371.89; Table 2) higher milk yield for crossbred cows comparing to HF cows, but without significance. The amount of LF and LFP were significantly $(p<0.01 ; p<0.001)$ higher in crossbreed comparing to Holstein Friesian cows (402.89, 4.46; 367.03, 4.22). Further, the LP was also higher in crossbreeds in comparison to HF (15.56 kg; Table 2), but not significantly. Heins et al. (2006) reported that pure HF had a significantly higher milk and protein production in 305 days than all crossbred groups, but pure Holsteins were not significantly different from Scandinavian Red x Holstein crossbreds for fat production. In the research of Malchiodi et al. (2011) Holstein cows did not differ $(p>0.05)$ from crossbreds for fat percentage and SCS, but they had significantly $(p<0.01)$ higher milk yield and lower protein content. According to results obtained by Heins and Hansen (2012), 
TABLE 1. Descriptive statistical analysis of the milk traits in standard (305 days) and full lactation for Holstein Friesian and F1 crossbred (HF $\times$ NRF) cows

\begin{tabular}{l|l|l|l|l|l|l|l|l|l|l}
\hline \multirow{2}{*}{ Traits } & \multicolumn{5}{|c|}{ HF (n=401) } & \multicolumn{5}{c}{ HF x NRF (n=57) } \\
\cline { 2 - 11 } & mean & SD & CV & MIN & MAX & mean & SD & CV & MIN & MAX \\
\hline M 305 & 8278.00 & 1750.03 & 21.14 & 2720.70 & 14206.90 & 8672.29 & 1826.57 & 21.06 & 4980.00 & 14102.70 \\
\hline M Lac & 9057.94 & 2293.76 & 25.32 & 2720.70 & 16610.90 & 9358.98 & 2287.80 & 24.45 & 4980.00 & 16497.10 \\
\hline SF & 343.10 & 77.30 & 22.53 & 120.90 & 637.40 & 378.32 & 71.95 & 19.02 & 225.70 & 541.10 \\
\hline LF & 377.04 & 99.13 & 26.29 & 120.90 & 738.20 & 409.02 & 87.88 & 21.49 & 225.70 & 630.70 \\
\hline SP & 274.20 & 52.60 & 19.18 & 97.80 & 447.40 & 291.26 & 53.61 & 18.41 & 172.00 & 421.50 \\
\hline LP & 301.90 & 72.64 & 24.06 & 97.80 & 531.70 & 315.66 & 69.26 & 21.94 & 172.00 & 494.10 \\
\hline SFP & 4.17 & 0.51 & 12.34 & 2.58 & 5.65 & 4.40 & 0.45 & 10.28 & 3.44 & 5.38 \\
\hline LFP & 4.19 & 0.51 & 12.10 & 2.58 & 5.60 & 4.42 & 0.44 & 9.88 & 3.60 \\
\hline SPP & 3.33 & 0.22 & 6.51 & 2.76 & 4.18 & 3.38 & 0.21 & 6.26 & 2.99 & 4.38 \\
\hline LPP & 3.35 & 0.22 & 6.57 & 2.79 & 4.18 & 3.40 & 0.21 & 6.25 & 2.99 & 4.03 \\
\hline DIM & 329.90 & 47.77 & 14.48 & 250.00 & 471.00 & 325.59 & 49.54 & 15.22 & 253.00 & 461.00 \\
\hline
\end{tabular}

M 305 = milk yield $(\mathrm{kg})$ in standard lactation; $\mathrm{M} \mathrm{Lac} \mathrm{=} \mathrm{milk} \mathrm{yield}(\mathrm{kg})$ in full lactation; SF = fat yield $(\mathrm{kg})$ in standard lactation; $\mathrm{LF}=$ Fat yield $(\mathrm{kg})$ in full lactation; $\mathrm{SP}=$ protein yield $(\mathrm{kg})$ in standard lactation; $\mathrm{LP}=$ protein yield $(\mathrm{kg})$ in full lactation; $\mathrm{SFP}=$ percentage value of the fat (\%) in standard lactation; LFP = percentage value of the fat (\%) in full lactation; SPP = percentage value of the protein (\%) in standard lactation; LPP = percentage value of the protein (\%) in full lactation; DIM = days in milk

TABLE 2. Least Squares Means of the milk traits for Holstein Friesian and crossbred (HF x NRF) cows

\begin{tabular}{l|l|l|l|l}
\hline Traits & HF & HF x NRF & Difference & P-value \\
\hline M 305 & 8190.91 & 8652.58 & -461.67 & $N^{2}$ \\
\hline M Lac & 8755.45 & 9127.34 & -371.89 & $N^{2}$ \\
\hline SF & 342.42 & 381.58 & -39.16 & $<0.001$ \\
\hline LF & 367.03 & 402.89 & -35.86 & $<0.01$ \\
\hline SP & 270.72 & 289.47 & -18.75 & $<0.05$ \\
\hline LP & 290.77 & 306.33 & $-15,56$ & $\mathrm{Ns}^{2}$ \\
\hline SFP & 4.20 & 4.49 & -0.29 & $<0.001$ \\
\hline LFP & 4.22 & 4.46 & -0.24 & $<0.001$ \\
\hline SPP & 3.32 & 3.37 & -0.05 & $\mathrm{Ns}^{2}$ \\
\hline LPP & 3.34 & 3.38 & -0.04 & $\mathrm{Ns}^{2}$ \\
\hline
\end{tabular}

${ }^{1}$ difference $=$ difference in the means of the two groups; ${ }^{2} \mathrm{Ns}=$ not significant, $\mathrm{P}>0.05 ; \mathrm{M} 305=$ milk yield (kg) in standard lactation; $\mathrm{M} \mathrm{Lac}=$ milk yield $(\mathrm{kg})$ in full lactation; $\mathrm{SF}=$ fat yield $(\mathrm{kg})$ in standard lactation; $\mathrm{LF}=$ Fat yield $(\mathrm{kg})$ in full lactation; $\mathrm{SP}=$ protein yield $(\mathrm{kg})$ in standard lactation; LP = protein yield ( $\mathrm{kg})$ in full lactation; SFP = percentage value of the fat (\%) in standard lactation; LFP = percentage value of the fat (\%) in full lactation; SPP percentage value of the protein (\%) in standard lactation; $\mathrm{LPP}=$ percentage value of the protein (\%) in full lactation 
crossbreeds of HF with Normand, Montbeliard and Scandinavian Red, had higher values of fat percentage across the five lactations comparing to pure Holstein from +0.11 to $+0.15 \%$. As for fat plus protein $(\mathrm{kg})$ in 305 days the same authors mentioned that crossbreeds had 3 to $10 \%$ lower values comparing to HF. Opposite results were obtained by Ezra et al. (2016), who state that Holsteins were higher for milk, fat and protein production comparing to crossbreeds in $\mathrm{F} 1$ generations. Ezra et al. (2016) also confirmed a slightly higher concentration (\%) for fat and protein of the F1 crosses comparing to pure Holstein, which agrees with the results of this research.

Conception rate for the $\mathrm{F} 1$ crosses was $1.58 \%$ better in comparison to HF cows. The number of inseminations per pregnancy (2.36: 2.79; Table 3.) was slightly better and also the duration of the days open (110.90: 133.10; Table 3.) were shorter for 22 days in $\mathrm{F} 1$ crosses than in HF cows, which can be supported by the results of Ezra et al. (2016), who reported a significantly $(p<0.001)$ better fertility in all three parities of the F1 crosses when compared to pure Holstein cows. Higher conception rates of F1 crosses (Swedish Red, Norwegian Red or Scandinavian Reds with Holstein) in comparison to pure Holstein cows were also established in researches of Heins and Hansen (2012), Malchiodi et al. (2014), Buckley et al. (2014) and Ezra et al. (2016). Heins and Hansen (2012) reported a lower value
TABLE 3. Fertility traits for the Holstein Friesian (HF) and F1 crossbred (HF x NRF) cows

\begin{tabular}{l|l|l|l}
\hline Traits & $\begin{array}{l}\text { HF } \times \text { NRF } \\
(\mathbf{n}=120)\end{array}$ & $\begin{array}{l}\text { HF } \\
(\mathbf{n}=255)\end{array}$ & Difference $^{1}$ \\
\hline $\begin{array}{l}\text { Conception } \\
\text { rate, } \%\end{array}$ & 33.44 & 31.86 & +1.58 \\
\hline $\begin{array}{l}\text { Insemination } \\
\text { per pregnancy, } \\
n\end{array}$ & 2.36 & 2.79 & -0.43 \\
\hline $\begin{array}{l}\text { Days open, } \\
\text { days }\end{array}$ & 110.90 & 133.10 & -22.2 \\
\hline
\end{tabular}

' difference $=$ difference between two groups $(\mathrm{HF} \times \mathrm{NRF}$; HF)

of SCC and better fertility traits of Scandinavian Reds and Holstein crossbreed in comparison to pure HF. Ferris et al. (2014) point out that crossbreeding Norwegian Red with Holsteins in Norway resulted in developing cows with improved calving ease, fewer stillbirths, reduced SCC, and improved fertility and longevity. Also, in this research a lower number of SCC in HF $x$ NRF was recorded in comparison to HF cows in full lactation (4.29: 4.58).

For the health traits, F1 crosses cows were slightly better in comparison to Holstein Friesian cows. For example, HF x NRF crosses had almost $12 \%$ less mastitis prevalence per cow, and from 0.5 to $4.8 \%$ less cases of ketosis, displaced abomasum

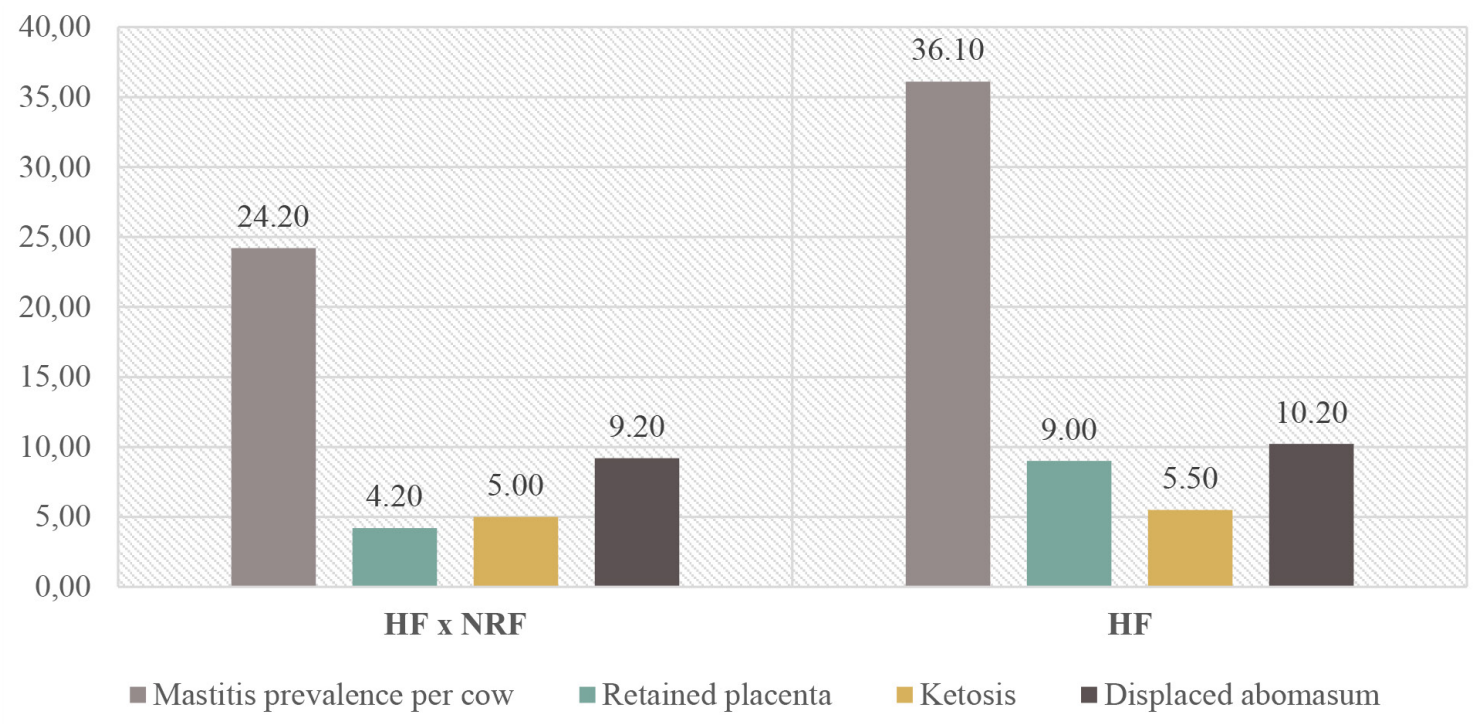

FIGURE 1. Prevalence of health disorders Holstein Friesian (HF) and F1 crosses (HF x NRF) cows 


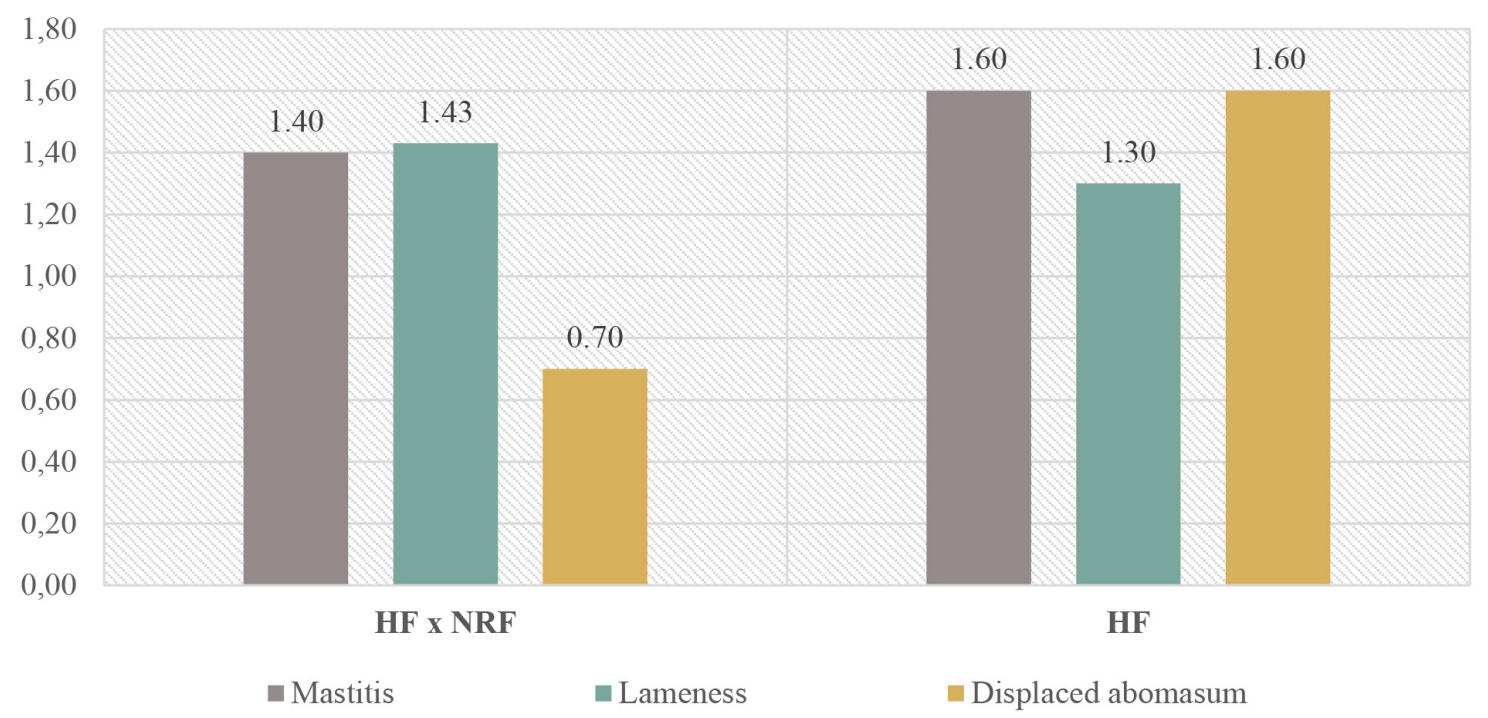

FIGURE 2. Percentage representation of reasons for culling of Holstein Friesian (HF) and F1 crosses (HF x NRF) cows

or retained placenta, when compared to HF cows (5.00: 5.50; 9.20: 10.20; 4.20: 9.00; Figure 1.). As to the reasons of culling, presented in Figure 2, HF $x$ NRF crosses had about $0.2 \%$ less culled cows because of mastitis (1.40: 1.60), and $0.9 \%$ less culled cows because of the displaced abomasum (0.70: 1.60) when compared to HF cows. Regarding the hoofs problem, F1 crosses had a slightly higher problem, which means that F1 crosses had approximately $0.13 \%$ more culled cows because of hoofs problem comparing to Holstein Friesian cows.

According to a recent study conducted by Nemes et al. (2014) which referred to crossing Serbian Fleckvieh cows with Holstein bulls, good working organization and breeding work leads to the optimal gene recombination, and maintenance of the necessary variability for the purpose of continual positive success of selection on the observed properties. After many years of planned selection, Nemes et al. (2014) obtained a pure desired type of Holstein. Following their results and the results obtained in this study, it can be inferred that further planned pairing of HF and NRF would provide generations with an improving health and fertility traits.

\section{Conclusions}

The obtained results indicate that F1 crossbreeds of Holstein Friesian with Norwegian Red cows had better production, fertility and health traits comparing to pure Holstein Friesian cows. Better F1 crossbreeds' performance could be a result of the expression of the heterosis effect. The subject of further research should be focused on examining to what extent the heterosis effect will be pronounced in subsequent lactations and whether it will result in higher longevity. Also, it is extremely important to define adequate pairing schemes in order to achieve the highest possible heterosis effect. 


\section{Proizvodne razlike između Holstein Friesian i F1 križanaca Holstein Friesian i Norwegian Red krava}

\section{Sažetak}

Cilj rada bio je usporediti proizvodna, zdravstvena i svojstava plodnosti krava Holstein Friesian (HF) pasmine i njegovih F1 križanaca sa Norwegian Red pasminom krava (HF x NRF F1). Za potrebe ovoga istraživanja korišteni su samo proizvodni podaci zaključenih prvih laktacija za ukupno 57 HF x NRF F1 križanaca i 401 HF krava, te za zdravstvena i svojstva plodnosti za 120 HF x NRF F1 križanaca i 255 HF krava. Značajnost razlika u proizvodnim svojstvima testirana je analizom varijance uporabom PROC GLM procedure u SAS-u. Proizvodnja mlijeka u obje laktacije (standardna 305 dana i puna laktacija) bila je veća kod HF x NRF F1 križanaca za približno 400 kg, ali bez utvrđene značajnosti. Proizvodna svojstva (mast i protein (kg i \%)) izuzevši protein u punoj laktaciji, bili su značajno veći $(p<0,001 ; p<0,05)$ kod HF x NRF F1 križanaca u usporedbi sa HF kravama. Gledajući svojstva plodnosti, HF x NRF F1 križanci su imali bolju koncepciju (+1,58 \%), manji broj osjemenjivanja krava po uspješnoj bređosti $(-0,43)$, te kraće trajanje servisnog razdoblja $(-22,2)$ u usporedbi sa HF kravama. HF x NRF F1 križanci su imala bolja zdravstvena svojstva (izuzev problema sa papcima) komparabilno sa HF kravama, odnosno imali su manje krava s mastitisom (-11,9\%), ketozom (-0,5\%), zaostalom posteljicom (-4,8 \%), te dislokacijom sirišta (-1,0\%). Obzirom da su rezultati dobiveni od krava sa završenom prvom laktacijom, potrebno je analizirati i podatke od narednih laktacija, kako bi se dobio puno jasniji uvid u istraživanu problematiku.

Ključne riječi: proizvodna svojstva, zdravstvena svojstva, svojstva plodnosti, Holstein Friesian, Norwegian Red 
1. Begley, N., Evans, R., Pierce, K., Buckley, F. (2009): Breed and heterosis estimates for milk production, udder health and fertility traits among Holstein and Norwegian Red Dairy Cattle. Proceedings of the $60^{\text {th }}$ Annual Meeting of the European Association for Animal Production, Barcelona, Spain, 206.

2. Buckley, F., Lopez-Villalobos, N., Heins, B.J. (2014): Crossbreeding: implications for dairy cow fertility and survival. Animal 8 (1), 122-133. https://doi.org/10.1017/S1751731114000901

3. Cartwright, S.L., Begley, N., Schaeffer, L.R., Burnside, E.B., Mallard, B.A. (2011): Antibody and cell mediated immune responses and survival between Holstein and Norwegian Red x Holstein Canadian calves. Journal of Dairy Science 94, 1576-1585. https://doi.org/10.3168/jds.2010-3502

4. Dechow, C.D., Rogers, G.W., Cooper, J.B., Phelps, M.I., Mosholder, A.L. (2007): Milk, fat, protein, somatic cell score, and days open among Holstein, Brown Swiss, and their crosses. Journal of Dairy Science 90, 3542-3549. https://doi.org/10.3168/jds.2006-889

5. Ericson, K., Danell, B., Rendel, J. (1988): Crossbreeding effects between two Swedish Dairy Breeds for Production traits. Livestock Production Sciences 20, 175-192. https://doi.org/10.1016/0301-6226(88)90071-1

6. Ezra, E., Van Straten, M., Weller, J.I. (2016): Comparison of pure Holsteins to crossbred Holsteins with Norwegian Red cattle in first and second generations. Animal 10 (8), 1254-1262. https://doi.org/10.1017/ S1751731116000239

7. Ferris, C.P., Patterson, D.C., Gordon, F.J., Watson, S., Kilpatrickt, D.J. (2014): Calving traits, milk production, body condition, fertility, and survival of Holstein-Friesian and Norwegian Red dairy cattle on commercial dairy farms over 5 lactations. Journal of Dairy Science 97, 52065218. http://dx.doi.org/10.3168/jds.2013-7457.

8. Hare, E., Norman, H.D., Wright. J.R. (2006): Survival rates and productive herd life of dairy cattle in the United States. Journal of Dairy Science 89, 3713-3720. https://doi.org/10.3168/jds.S0022-0302(06)72412-2

9. Heins, B.J., Hansen, L.B., Seykora, A.J. (2006): Production of Pure Holsteins Versus Crossbreds of Holstein with Normande, Montbeliarde, and Scandinavian Red. Journal of Dairy Science 89, 2799-2804. https://doi.org/10.3168/jds.S0022-0302(06)72356-6

10. Heins, B.J., Hansen, L.B. (2012): Short communication: fertility, somatic cell score, and production of Normande $x$ Holstein, Montbeliarde x Holstein, and Scandinavian Red $x$ Holstein crossbreds versus pure Holsteins during their first 5 lactations. Journal of Dairy Science 95, 918-924. https://doi.org/10.3168/jds.2011-4523
11. Malchiodi, F., Penasa, M., Tiezzi, F., Bittante, G. (2011): Milk Yield Traits, Somatic Cell Score, Milking Time and Age at Calving of Pure Holstein Versus Crossbred Cows. Agriculturae Conspectus Scientificus 3, 259-261.

12. Malchiodi, F, Cecchinato, A., Bittante, G. (2014): Fertility traits of purebred Holsteins and 2- and 3-breed crossbred heifers and cows obtained from Swedish Red, Montbéliarde, and Brown Swiss sires. Journal of Dairy Science 97, 7916-7926. https://doi.org/10.3168/jds.2014-8156

13. Nemes, Z., Vidović, V., Lukač, D., Ivanković, A., Grubić, G., Komlósi, I., Gáspárdy, A. (2014): Estimation of nonadditive genetic impacts on lifetime performance through a grading-up breeding program with Holstein-Friesian. Mljekarstvo 64 (4), 261-267.

https://doi.org/10.15567/mljekarstvo.2014.0405

14. Rinell, E., Heringstad, B. (2018): The effects of crossbreeding with Norwegian Red dairy cattle on common postpartum diseases, fertility and body condition score. Animal 12 (12), 2619-2626. https://doi.org/10.1017/S175173111800037X

15. Seegers, H., Fourichon, C., Beaudeau, F. (2003): Production effects related to mastitis and mastitis economics in dairy cattle herds. Veterinary Research 34, 475-491. https://doi.org/10.1051/vetres:2003027

16. Sørensen, M.K., Norberg, E, Pedersen, J., Christensen, L.G. (2008): Crossbreeding in dairy cattle: a Danish perspective. Journal of Dairy Science 91, 4116-4128. https://doi.org/10.3168/jds.2008-1273.

17. Touchberry, R.W. (1992): Crossbreeding effects in dairy cattle: The Illinois experiment, 1949 to 1969. Journal of Dairy Science 75, 640-667. https://doi.org/10.3168/jds.S0022-0302(92)77801-1

18. VanRaden, P.M., Sanders, A.H. (2003): Economic merit of crossbred and purebred US dairy cattle. Journal of Dairy Science 86, 1036-1044. https://doi.org/10.3168/jds.S0022-0302(03)73687-X

19. Weigel, K.A., Barlass, K.A. (2003): Results of a producer survey regarding crossbreeding on US dairy farms. Journal of Dairy Science 86, 4148-4154. https://doi.org/10.3168/jds.S0022-0302(03)74029-6

20. Weigel, K.A. (2007): Crossbreeding: A dirty word or an opportunity? Proceedings of the Western Dairy Management Conference, Reno, NV.

21. Weller, J.I. (1994): Economic aspects of animal breeding. Chapman and Hall, London, UK. 244 pp.

22. Windig, J.J., Calus, M.P.L., Veerkamp, R.F. (2005): Influence of herd environment on health and fertility and their relationship with milk production. Journal of Dairy Science 88, 335-347. https://doi.org/10.3168/jds.S0022-0302(05)72693-X 